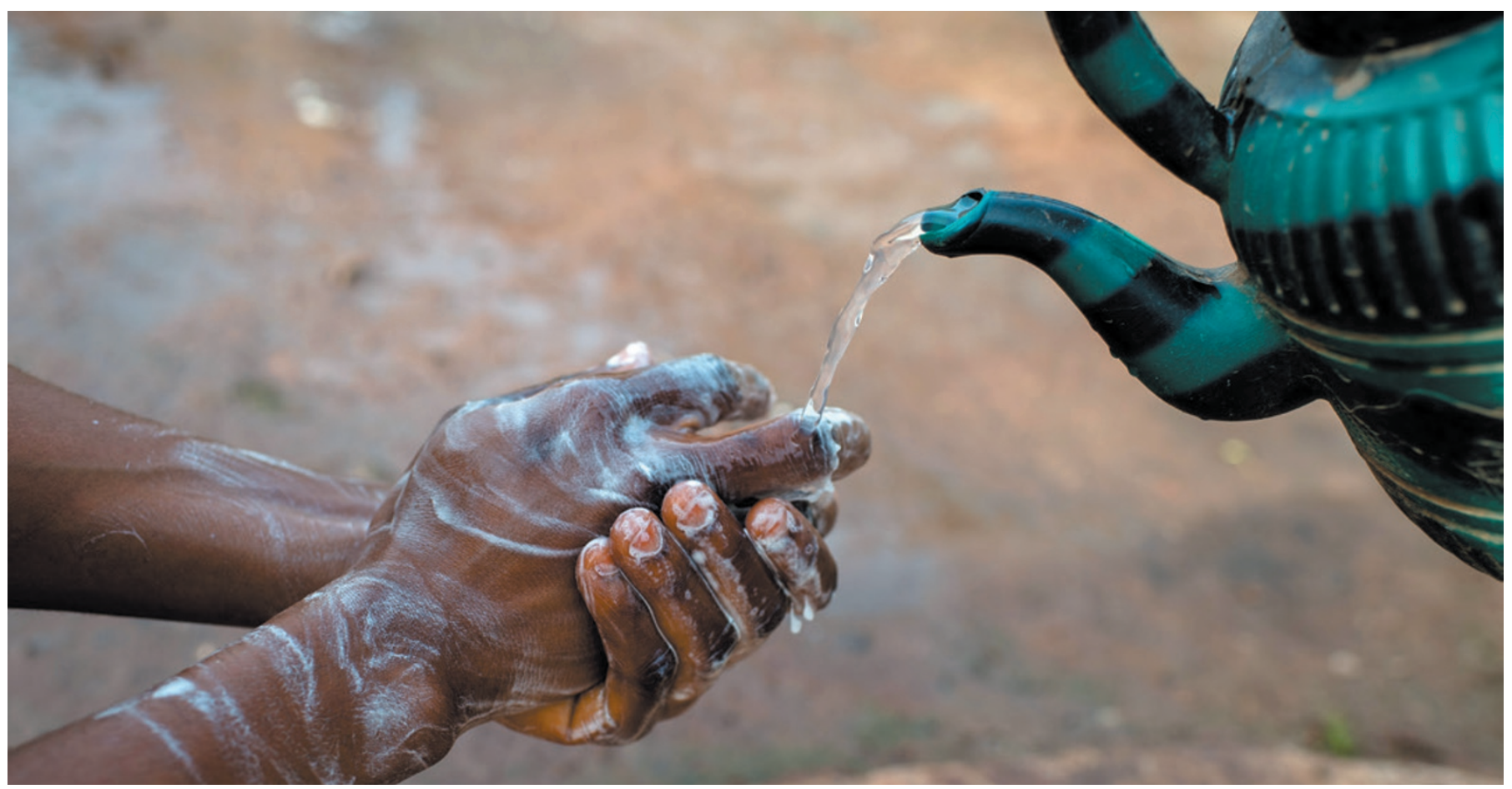

A health nurse in Ghana washes her hands before examining a baby.

\title{
Pathogens in perspective
}

\section{Andrew Jermy travels with Hugh Pennington on the arc of humanity's long, troubled relationship with microorganisms.}

\section{$\mathrm{B}$} efore opening Hugh Pennington's Have Bacteria Won?, readers of newspaper headlines might presume that his answer is 'yes'. But for the most part, the eminent bacteriologist comes to the opposite conclusion in this thought-provoking study that documents the history of human interactions with infectious disease and how current fears of impending doom have developed.

Pennington draws on personal experience and illuminating case studies — such as the United Kingdom's experience with bovine spongiform encephalopathy (BSE) and variant Creutzfeldt-Jakob disease - to show how the public perception and clinical reality of infectious disease can be at odds. He upbraids researchers, journalists and editors (such as me) for using the hyperbolic language of war (fight, struggle, arms race) to describe our relationship with the microorganisms that colonize and infect our bodies. Such language injects drama and elevates the importance of events, much more than dry but accurate descriptions of the consequences of interactions between microbe, host, immune response and treatment.

As a result, the fear of microbial life in the collective mind is often vastly out of proportion to the risk. As Pennington puts it, "the media behave like a cheap refracting telescope, focusing on an object of interest but magnifying it with a good deal of aberration and fuzziness at the edges". Witness the media hysteria in

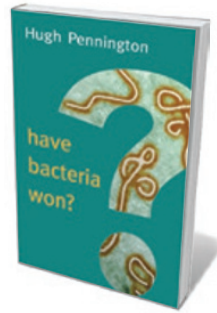

Have Bacteria Won? HUGH PENNINGTON Polity: 2015 2014 when US nurse Kaci Hickox returned to Maine from Sierra Leone after working with Médecins Sans Frontières (also known as Doctors Without Borders). Hickox was wrongly suspected of infection with Ebola, and her return set in train legal proceedings relating to her quarantine.

Oddly, Pennington then fails to heed his own critique about rhetoric. He tours some of our "victories" (against smallpox, diphtheria and syphilis); the "advance" of microorganisms such as Escherichia coli and MRSA - methicillin-resistant Staphylococcus aureus - through horizontal transfer of toxin-encoding genes or selection for antibiotic resistance; and the "battles" in which human actions have helped microorganisms (including Salmonella and the organisms that cause anthrax and legionnaires' disease). He deftly weaves historical vignettes into the greater journey. These include early efforts to control smallpox in the eighteenth century, led by Lady Mary Wortley Montagu, US minister Cotton Mather and latterly Edward Jenner; the benefits of improved water availability (originally intended to support trade and fight fire); sanitation, diet and pasteurization in the nineteenth century; and on to the discovery of antibiotics in the twentieth century, right up to outbreaks of carbapenemresistant Enterobacteriaceae and severe acute respiratory syndrome (SARS) coronavirus in the modern era. The arc of that story and Pennington's accessible prose grip throughout.

Pennington points out that infection with antibiotic-resistant bacteria is not new. It has followed closely in the footsteps of all antibiotics since penicillin - discovered by Alexander Fleming in 1928 - was developed as a treatment by Howard Florey and Ernst Chain. In another bout of debunking, 
Pennington argues that predictions of a coming antibiotics Armageddon leading to a substantial increase in infection-related deaths are greatly exaggerated. On this point, I take a more cautious line. It is true that careful management and aseptic technique can have an important role in husbanding a dwindling supply of drugs effective against the most serious infections. However, Pennington does not devote sufficient space to the factors that have led the antibiotic-development pipeline to dry up in recent years.

He almost trivializes the difficulties in identifying relevant natural products or chemical constructs and developing them into usable drugs, simply writing: "New antimicrobials will be very welcome. Getting them ready for rollout will be expensive and will take years." And he skates over structural problems in the pharmaceutical industry: we urge pharma to develop antimicrobials while simultaneously planning to limit their use drastically. In the twentieth century, drugs came along in time to take over when resistance arose; whether that will be the future pattern is uncertain.

Pennington also skimps on coverage of microscopic eukaryotic pathogens, such as the malarial parasite Plasmodium falciparum or the fungi that cause cryptococcal meningitis. His only mention of malaria is in relation to Nobel-prizewinning Austrian physician Julius Wagner-Jauregg's use of Plasmodium infection as an experimental antimicrobial agent to trigger the inflammation necessary to kill Treponema, the spirochaete that causes syphilis. Yet malaria currently kills more than 500,000 people a year, and the spread in southeast Asia of resistance to the only effective antimalarials is of global concern.

As Pennington admits, Have Bacteria Won? is intentionally biased by his personal experience as an infectious-disease specialist working in the United Kingdom. It would be unreasonable to expect comprehensive coverage in an overview for the generalist. But he could have better explored the idea that developed countries are over-fearful about infectious diseases, whereas developing nations - struggling with poor sanitation and inadequate clean water, nutrition and health care — are at greater, and globally significant, risk.

The book's title notwithstanding, Pennington extends his analyses to diseases caused by viruses, prions and eukaryotic parasites. Microbiologists grind their teeth when a wellintentioned news report refers to a bacterial infection as caused by a virus, or vice versa, so why sow more confusion? However, these few concerns do not detract from what is an entertaining and very well-written primer on the human-microbe relationship - one of the oldest pairings on Earth.

Andrew Jermy is chief editor of Nature Microbiology.

e-mail:a.jermy@nature.com

\section{Books in brief}

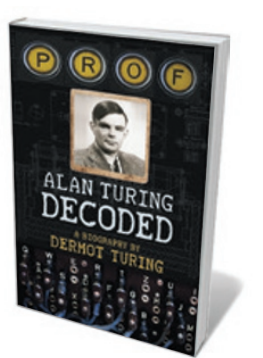

Prof: Alan Turing Decoded

Dermot Turing THE HISTORY PRESS (2015)

Computing pioneer Alan Turing has been justly and amply lauded, not least in these pages (see Nature 515, 195-196 (2014) and nature. com/turing). Now, a biography by his nephew, Dermot Turing, offers new sources and a refreshingly familial tone. We see the stubbornly original young Alan finding his way in maths and society; mentors such as Max Newman, who kick-started Turing's obsession with machines; the design of the electromechanical 'bombe' that helped to crack the Enigma cipher; and a sensitive reappraisal of Turing's suspected suicide. A measured portrait at ease with its subject.

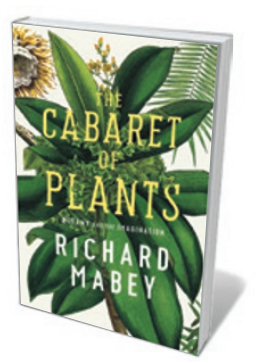

The Cabaret of Plants: Botany and the Imagination

Richard Mabey PROFILE (2015)

As a celebrant of the botanical, Richard Mabey has few peers. He is on eloquent form in this portrayal of plants not as dully functional components of natural capital — a "biological proletariat" — but as unruly, autonomous and endlessly fascinating. This engaging scientific and cultural tour takes in ice-age engravings of plant forms; ancients and giants such as bristlecone pines and baobabs; the vast biodiversity of maize (corn); and, as touched on by plant scientist lan Baldwin (Nature 522, 282-283; 2015), Erasmus Darwin's discovery of "irritability" in Mimosa pudica more than 200 years ago.

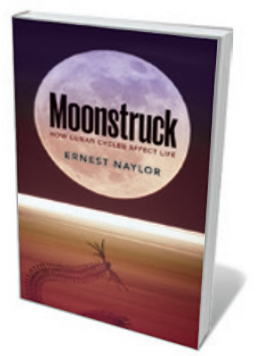

\section{Moonstruck: How Lunar Cycles Affect Life}

Ernest Naylor OXFORD UNIVERSITY PRESS (2015)

Circadian rhythms are dictated by sunlight and stitched into our genes. But what of the impact of moonlight on life? Marine biologist Ernest Naylor reveals that behavioural patterns linked to lunar phases have been found in animals such as the sea louse Eurydice. He also examines Moon-related spawning behaviour in marine species such as grunion and horseshoe crabs, and the sooty tern (Onychoprion fuscatus), with its breeding cycle of ten lunar months. For context, Naylor gives us the "full Moon": the deep history, classical science and myth surrounding Earth's beautiful, enigmatic satellite.

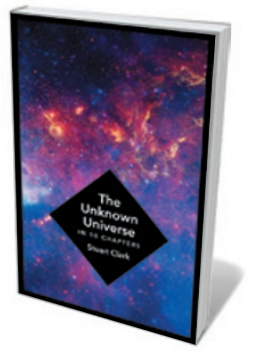

The Unknown Universe: What We Don't Know About Time and Space in Ten Chapters

Stuart Clark HEAD OF ZEUS (2015)

It is no revelation that some data on the early Universe sit uneasily with the standard model of cosmology. But in his clued-up overview, astronomy journalist Stuart Clark's picture of the yawning gaps in our understanding of the cosmos is fuller than most. Clark tacks back and forth in the history of astronomy, intertwining the discoveries and theories of luminaries from astronomer William Herschel to cosmologist Roger Penrose with speculation on prevailing mysteries such as the nature of dark matter, dark energy and space-time.

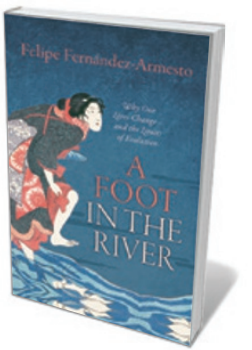

\section{A Foot in the River: Why Our Lives Change — and the Limits of} Evolution

Felipe Fernández-Armesto OXFORD UNIVERSITY PRESS (2015)

Cultural evolutionists paint a partial picture of the speed of change in human cultures, argues historian Felipe Fernández-Armesto. His study, springing from a conference sponsored by the Templeton Foundation, calls for a new interdisciplinarity. He argues that although human culture is born of evolution, it also "changes independently of evolution" because it is a "projection of the human mind" — and its prodigious imaginative capacity. Barbara Kiser 